\title{
Economics and Tobacco Regulation
}

\author{
Carole Mireille Mende B.D. \\ Nelson Mandela College of Government \& Social Sciences, Southern University and A\&M College, LA, USA
}

\begin{abstract}
Taxation is a crucial tool in the effort to attain a tobacco-free world. According research, increases in tobacco taxes have a positive correlation with the reduction of tobacco consumption. Even though the tobacco industry is among the successful industries, tobacco consumption kills more people than any other product. This paper through the lens of economics discusses the role of taxation in tobacco consumption. It discusses tobacco taxation as a tool to discourage smoking. Increasing tobacco taxes passed on to consumers in the form of higher tobacco product prices, is one of the most effective ways to prevent and reduce tobacco use. Placing higher prices on tobacco products encourage tobacco users to quit, helps sustain cessation and reduce consumption of tobacco among those who use tobacco.
\end{abstract}

Keywords: Economics, Tobacco regulation, taxation, cessation

DOI: $10.7176 / \mathrm{JESD} / 11-2-13$

Publication date: January $31^{\text {st }} 2020$

\section{Introduction}

Louisiana received $\$ 477.4$ million (estimated) in tobacco settlement payments and taxes in fiscal year 2018 (Campaign for Tobacco-Free kids, 2018). Of this, the state allocated $\$ 5.8$ million in state funds to tobacco prevention in fiscal year 2018, just 9.7 percent of the Centers for Disease Control and Prevention's annual spending target. Smoking-related health care costs: \$1.89 billion per year Smoking-related losses in productivity: \$2.49 billion per year Smokeless tobacco is taxed at 20 percent of the invoice price and smoking tobacco is taxed at 33 percent of the invoice price (Campaign for Tobacco-Free kids, 2018; Truth Initiative, 2019). Cigars are taxed between 8 percent and 20 percent, depending on the manufacturer's invoice price. E-cigarettes and vapor products are taxed at 5 cents per milliliter of consumable nicotine liquid solution (American Lung Association, 2018)

In it's third special session, it approved a partial extension of the state's temporary sales tax hike. A one percent increase in the sales tax was scheduled to expire July 1, but after heated debate, legislators have approved an extension at a lower rate, a .45 percent increase. As of July 1, the state sales tax rate will be 4.45 percent (Campaign for Tobacco-Free kids, 2018).

\section{Tobacco taxes}

The most common forms of domestic consumption taxation levied on tobacco products are (Value Added Taxes) VAT and Excises.

Excise taxes are legislated taxes paid when purchases are made on a specific good such as tobacco, gasoline and alcohol; specific and ad valorem are two types of excise taxes. A specific excise tax is a fee added to tobacco per-unit (e.g. pack, weight, piece) of tobacco products. An ad valorem excise tax is paid as a percentage of the overall value of the tobacco products. In the ad valorem taxation, firms have an incentive to increase production because price falls when supply increases. But part of the price reduction is borne by the tax office, since the per unit tax payment falls (Farrelly, 2000; WHO, 2010). That is, under ad valorem taxation government "subsidizes" production expansion and lower prices. Along the same lines, if producers increase prices, part of the increase in prices accrues to government as tax revenue. Under specific taxation, fixed prices are applied to certain purchases. Any increase in the producer's price go as revenue (to the producer), and thus would increase producers' incentive to raise prices of their products (Keeler, 1996). The choice between specific and ad valorem taxes is a long-standing issue in tax policy, and both the level and the structure of excises have different implications for the interests and goals of various groups. Given the market structure of the tobacco industry, a monopoly or oligopoly for most products in most countries. Different excises may have a different effect on government's revenues, manufacturer's profit, consumer's price, product's "quality" and variety, and ability to administer taxes (Sullivan, 2012; WHO, 2010). Consequently, the two types of excise taxes may have different implications for public health through their impact on product "quality", variety, and prices in the extent they affect individual consumption. Moreover, governments have the potential to manipulate tobacco excises to manage demand, raise revenue and promote public health (Johnson, 1978). A challenge for policy makers is how to choose which type of excise to levy and at what rate or find the appropriate balance between specific and ad valorem taxation, so that the public health objective is achieved while generating higher revenues. Ad valorem taxation has a multiplier effect that favours low "quality": for example, to cover the costs of a $\$ 1$ "quality" improvement requires $\$ 1$ more pre-tax revenue under specific taxation, but $\$ 1.25$ more if the tax is ad valorem at a tax-inclusive rate of $20 \%$ (Goolsbee, 2010). Tax generates a price increase higher than the cost of package that means, under ad valorem taxation, as 
producers increase their prices to cover the cost of improvements, tax revenue by the government increases as well due to the multiplier effect. Any increase in the ad valorem tax makes markets relatively more competitive, which causes the exit of some firms (brands), reducing product variety in the market. The result that specific taxation is favorable to more appealing high-priced cigarettes is important from the tobacco control point of view (Anderson, 2001; WHO, 2010).

Value Added Taxes: VAT is a tax placed on a product whenever value is added from production to the point of sale. It is a general tax on consumption of goods and services which leaves relative prices unaffected. As such has great practical appeal for revenue generation. It records only the total value of sales needed and minimizes the amount of detailed information needed for tax administration Tax authorities have no need to be concerned with the nature of the goods and services traded (Barzel, 1976; WHO, 2010).

The base on which taxes are levied can take many forms. When the tax is uniform, that is, the same rate applies to all cigarettes, the tax base can be on

1. Quantity: The most common base for a specific excise is a pack of 20 cigarettes or a tax per 1,000 cigarettes. (WHO, 2010)

2. Price: The ad valorem excise may be applied based on the manufacturer's price or the retail price. In some countries, the specific excise varies by tiers, typically depending on the characteristics of brands. (WHO, 2010)

\section{Industry profit Theory}

This theory shows that profits are relatively higher under specific taxation (a tax increase may lead to an increase in profits). More than $100 \%$ over-shifting is a requisite for an increase in profits: as a higher tax increases consumer price and reduces demand, for profits to rise, the after-tax markup must rise (Kyang, 2003). It is not a surprise that tobacco multinationals prefer specific taxes. Along with increases in the specific tax, governments may find they need to implement other policies to counteract the tobacco industry's increased market power. Generally, the level of revenue from each tax varies according to the market characteristics. Governments care not only about its level but also its certainty and stability, as well as the ease of administration and enforcement (Paton, 2001).

\section{Level of tax revenue Theory}

This theory suggests that there is probably an optimal balance between ad valorem and specific excises in terms of maximizing government revenue, assuming this is the government's objective, and/or minimizing variations in tax revenues. As prices are affected both directly and indirectly by taxes through their effect on "quality" and the number of different brands available in the market, consumers may consume less of their preferred brand, may consume the same units as before but of a cheaper brand, or may consume less of a more expensive brand (Paton, 2001). Finding an accurate way of predicting revenue is quite difficult as one must forecast changes in consumer behavior. Other than the changes induced by price increase, if we want to eliminate changes in consumer behavior, other forms of taxation that have the least effect on product characteristics should imposed. (Anderson, 2001).

Since specific excises are independent of changes in price, they are more likely to produce a stable stream of government revenue. As taxes increase, the industry also increases its own price, but the level of increase is not certain; this fact is likely to cause uncertainty in the level of the tax-inclusive consumer price. In general, when there is price uncertainty, price elasticity plays a crucial role in the determination of the type of excise levied on cigarettes to ensure expected tax revenue or to eliminate the variation in revenue. Cigarette consumption will not change as price changes, if demand is completely inelastic (Johnson, 1978). In such a case, as quantity remains constant after a tax increase, taxing quantity (i.e. specific taxation) would remove any variations in government revenue. Alternatively, if demand elasticity is constant, consumers spend on cigarettes the same amount of income no matter what the price level; in this case, ad valorem taxation ensures more stable government revenue. However, research shows that cigarette demand elasticity is somewhere between zero and one in most countries (WHO, 2010). Specific taxes are much easier to administer. Once the 'unit' of quantity is defined, the government revenue can be collected at any stage (e.g. manufacturer, wholesaler or importation). In ad valorem taxation, the government relies on the manufacturers' declaration of price at manufacturing or retail level. To avoid undervaluation, technically sound tax administration and awareness of the manufacturers' pricing policies are required. From a public health point of view, however, distorting product characteristics (not just prices) might be desirable (Barzel, 1976).

Ad valorem taxation is more likely to involve valuation problems, especially if the tax base is the manufacturer's price. That is, in the ad valorem taxation, tobacco manufacturers can sell their products to other companies at a low price, in order to reduce the excise tax liability (transfer pricing). Consequently, the government revenue from ad valorem tax declines due to the reduction in tax base. Keeping pace with inflation: An ad valorem tax maintains revenue value under high inflation given that the amount of the tax increases as prices increase, while specific taxes need to be adjusted with the Consumer Price Index (CPI) to keep pace with inflation (Paton, 2001).

In specific taxation, manufacturers can manipulate the length and size of a cigarette or its pack to reduce tax 
payment. Minimization of incentives for tobacco users to switch to cheaper brands or products in response to tax increases and improvement of tobacco tax administration to reduce opportunities for tax avoidance and tax evasion are included as best practices for adoption of a relatively simple tax system that applies equivalent taxes to all tobacco products (Farrelly, 2000). Combined with strong tax administration, adequate enforcement and severe penalties on violators, such a tax system will have the greatest public health impact, while at the same time produce a more stable, reliable stream of tax revenues (Sullivan, 2012)

\section{Tax over-shifting}

Tax over-shifting means that, when tax increases, the consumer price rises by more than the tax increase itself. The impact of specific taxes on prices, is consistent with a greater possibility of over-shifting of such a tax. When taxes are increased, prices are usually adjusted to reflect not only the tax increase but also other cost increases during the last year or so. Cigarette taxes lead to significant price increases, more than double the size of the tax increase, and this could not be explained by increases in manufacturing costs (Chaloupka, 2000). Under specific taxation, any increase in producer's price will go to the producer as revenue, and thus would increase producers' incentive to raise prices of their products. This is not the case under ad valorem taxation, as part of the increase in prices accrues to government as tax revenue. Specific excises provide incentives for more appealing and higherpriced products, as well as greater variety. Producers' ability to pass taxes to consumers depends on market power. Producers go through great lengths to differentiate their products as product differentiation creates some monopoly power (Siegel, 1999). Product differentiation can be vertical or horizontal. In vertical differentiation, firms produce a product, but its quality varies; all consumers prefer the best quality or, in terms of cigarettes, the most appealing brand, but differ in their willingness to pay for it meanwhile in horizontal differentiation, firms produce different versions of a product. (Schneider, 2000).

\section{Conclusion}

In other to encourage tobacco users to quit, increasing the price of tobacco through higher taxes is an effective way to do it. Increasing tobacco taxes passed on to consumers in the form of higher tobacco product prices, is one of the most effective ways to prevent and reduce tobacco use. Placing higher prices on tobacco products encourage tobacco users to quit, helps sustain cessation and also reduce consumption of tobacco among those who use tobacco. The revenue generated in tobacco tax increases can be used to provide much funding tobacco control programs. Therefore, tobacco control advocates should continue to support the imposition of higher tobacco taxes (CDC, 2016). They should also promote tobacco tax equity, to ensure that other tobacco products are taxed at rates like those imposed on cigarettes

Tobacco control measures such as the demand-reduction measures e.g. higher taxes, bans on advertisement, and the helping of those who want to quit tobacco usage are effective in reducing tobacco usage. With all the benefits of these tobacco prevention measures, different governments have been reluctant in implementing strong tobacco control policies because of the negative effect of these policies on the economy (CDC, 2018)

\section{REFERENCES}

1. Anderson, Simon P., et al (2001). "Tax Incidence in Differentiated Product Oligopoly.” Journal of Public Economics. 81: 173-192.

2. Barzel, Yoram. (1976). "An Alternative Approach to the Analysis of Taxation.” Journal of Political Economy. 84 (6): 1177-1197.

3. Center for Disease Control. (2011). Economic Facts About U.S. Tobacco Production and Use. Accessed June 19: http://www.cdc.gov/tobacco/data_statistics/fact_sheets/economics/econ_facts/.

4. Chaloupka, Frank J., et al (2000). The Economics of Smoking. In The Handbook of Health Economics, Volume 1B, edited by Anthony and Joseph Newhouse, 1539-1627. Amsterdam: Elsevier.

5. Goolsbee, Austan, Michael Lovenheim, and Joel B. Slemrod. (2010). "Playing With Fire: Cigarettes, Taxes, and Competition from the Internet." American Economic Journal: Economic Policy. 2: 131-154.

6. Johnson, Terry R. (1978). "Additional Evidence on the Effects of Alternative Taxes on Cigarette Prices." Journal of Political Economy. 86 (2): 325-328.

7. Keeler, Theodore E., et al (1996). "Do Cigarette Producers Price-Discriminate by State? An Empirical Analysis of Local Cigarette Pricing and Taxation.” Journal of Health Economics. 15 (4): 499-512.

8. Sullivan, Ryan S. and Donald H. Dutkowsky.(2012). "The Effect of Cigarette Taxation on Prices: An Empirical Analysis Using Local-Level Data.” Public Finance Review. 40 (6): 687- 711.

9. Campaign for Tobacco-Free Kids, Toll of Tobacco in the United States, 2018 accessed at https://www.tobaccofreekids.org/what-we-do/us/statereport

10. American Lung Association, SLATI State Reports, 2017 accessed at http://www.lung.org/ourinitiatives/tobacco/reports-resources/sotc/

11. American Lung Association, State of Tobacco Control, 2018 accessed at http://www.lung.org/our 
initiatives/tobacco/reports-resources/sotc/

12. Campaign for Tobacco-Free Kids, State Cigarette Excise Tax Rates \& Rankings, 2018 accessed at https://www.tobaccofreekids.org/assets/factsheets/0097.pdf

13. Guiljuan Lin (2009), Higher Education Research Methodoly- Literature Method. International education studies.

14. Louisiana Department of Revenue, "Revenue Information Bulletin 18-016,"revenue.louisiana.gov, 2018, http://revenue.louisiana.gov/LawsPolicies/RIB\%2018-

016\%20Decrease $\% 20 \mathrm{in} \% 20$ State $\% 20$ Sales $\% 20$ Tax\%20Rate $\% 20$ to $\% 20$ be $\% 20$ Effective $\% 20 J u l y \% 201 \% 20$ 2018.pdf.

15. U.S. Centers for Disease Control and Prevention. Best Practices for Comprehensive Tobacco Control Programs. Atlanta GA: U.S. Department of Health and Human Services, Public Health Service, Centers for Disease Control and Prevention, National Center for Chronic Disease Prevention and Health Promotion, Office on Smoking and Health.

16. CDC, State-Specific Prevalence of Tobacco Product Use Among Adults - United States, 2014-2015, MMWR.

17. Farrelly MC, et al (2003). The impact of tobacco control program expenditures on aggregate cigarette sales: 1981-2000. 2003;22:843-59.

18. Warner KE .(2000). The economics of tobacco: myths and realities. 2000;9:78-89.FREE Full Text.

19. Kyaing NN (2003). Tobacco Economics in Myanmar. HNP Discussion Paper. Washington DC: The World Bank, 2003

20. Campaign for Tobacco-Free Kids, State Cigarette Excise Tax Rates \& Rankings, 2018.

21. CDC, Behavioral Risk Factor Surveillance System, State Tobacco Activities Tracking and Evaluation System, 2016.

22. Campaign for tobacco-free kids, 2018 accesshttps://www.tobaccofreekids.org/assets/factsheets/0097.pdf

23. Paton, David and Vaughan Williams, Leighton (2001). 'Monopoly rents and price fixing in betting markets', Review of Industrial Organization, vol. 19(3), pp. 265-78.

24. American Lung Association, SLATI State Reports, 2017.

25. American Lung Association, State of Tobacco Control, 2018.

26. Sauer, Raymond D. (2001). 'The political economy of gambling regulation', Managerial and Decision Economics, vol. 22(1), pp. 5-15.

27. Schneider, Friedrich and Enste, Dominik H. (2000). 'Shadow economies: size, causes and consequences', Journal of Economic Literature, vol. 38(1), pp. 77-114.

28. CDC, Behavioral Risk Factor Surveillance System, 2016.

29. CDC, Youth Risk Behavior Surveillance System, 2017.

30. WHO, $2010 \mathrm{http} / / \mathrm{www}$.who.int/tobacco/publications/en_tfi_tob_tax_chapter2.pdf

31. Campaign for Tobacco-Free Kids, Broken Promises to Our Children: a State-by-State Look at the 1998 State Tobacco Settlement 19 Years Later FY2018, 2017.

32. Campaign for Tobacco-Free Kids, Toll of Tobacco in the United States, 2018. 